Wykorzystane w pracy materiały źródłowe były częściowo do tej pory, albo wcale nie znane, albo w niewielkim stopniu wykorzystywane, wreszcie błędnie interpretowane. W książce wykorzystane zostały zarówno materiały rękopiśmienne, jak i drukowane, polskie i obce - francuskie, włoskie. Do tych niewątpliwych walorów merytorycznych pracy dodać trzeba, iż jest ona napisana poprawną, ładną polszczyzną, wyposażona w bogate, wyczerpujące i przejrzyste przypisy, interesujące, stanowiące wzbogacenie narracji ilustracje, a poruszanie się po tekście i korzystanie z zawartych w nim informacji ułatwia indeks nazwisk oraz to, że praca została doskonale opracowana pod względem edytorskim.

Najnowsza praca Kazimierza Puchowskiego jest kolejnym krokiem w poznawaniu działalności edukacyjnej Towarzystwa Jezusowego, pokazuje jak zakon dostosowywał się do zmieniających się okoliczności i potrzeb społecznych, wszakże początkowo jezuici niechętni byli tworzeniu tego typu instytucji i dopiero pod wpływem nacisków, można powiedzieć, zaczęli je powoływać.

Dorota Żołądź-Strzelczyk

\title{
Lidia Burzyńska-Wentland, Strajki szkolne w Prusach Zachodnich w latach 1906-1907, Wydawnictwo Uniwersytetu Gdańskiego, Gdańsk 2009, ss. 255
}

Historia walki o polskość w zaborze pruskim w początkach XX w. wzbogacona została o pracę Strajki szkolne w Prusach Zachodnich w latach 1906-1907 wydaną przez Wydawnictwo Uniwersytetu Gdańskiego. Mając na uwadze, że język narodowy stanowi podstawowy element tożsamości narodowej i dobro kultury narodowej oraz doświadczenia historyczne z okresu zaborów, kiedy walka z językiem polskim była narzędziem wynaradawiania $^{1}$ wydanie wymienionej publikacji monograficznej w szczególności zasługuje na uwagę.

Praca jest przede wszystkim syntezą badań własnych autorki ${ }^{2}$ Praca - jak autorka pisze we „Wstępie” - stanowi próbę całościowego ujęcia problemu strajków szkolnych z lat 1906-1907 na tle zagadnień spotecznych, ekonomicznych i prawnych charakterystycznych dla tego obszaru ziem polskich pod rzadami pruskimi. Celem pracy jest pogtębienie dotychczasowych badań nad przyczynami wybuchu strajków w Prusach Zachodnich. L. Burzyńska-Wentland podjęła także próbę dokonania weryfikacji dotychczasowych ustaleń dotyczących zasięgu terytorialnego oraz liczby dzieci uczestniczących w strajku oraz ukazania skali represji władz pruskich w związku z strajkami szkolnymi.

\footnotetext{
1 Ustawa z dnia 7 października 1999 r. o języku polskim (Dz. U. z 1999 r. Nr 90, poz. 999 z późn. zm.).

2 Recenzowana publikacja monograficzna zawiera 203 stron tekstu autorskiego, 14 aneksów na 32 stronach, 191 pozycji bibliograficznych, 943 przypisy ( w tym rozdział I - 164, rozdział II - 242, rozdział III 210, rozdział IV - 291, zakończenie - 36).
} 
W recenzji wydawniczej książki pióra prof. zw. dr. hab. Stanisława Gawlika, zamieszczonej na okładce publikacji, czytamy, że doktor Lidia Burzyńska-Wentland, która jest pracownikiem naukowo-dydaktycznym w Zakładzie Historii Nauki i Wychowania Instytutu Pedagogiki Uniwersytetu Gdańskiego, podjęła w prowadzonych przez siebie badaniach naukowych zagadnienie oświatowe o znaczeniu historyczno-społecznym i pedagogicznym. S. Gawlik stwierdza, że autorka pracy osiągnęła nakreślony cel badań naukowych. Zadbała o wyjątkowo pokaźny zasób źródeł literatury, wykazała wyjątkowo wyskoki poziom umiejętności w zakresie zgromadzonego piśmiennictwa dotyczącego tematu pracy. Tym samym przedstawiła dzieło warsztatowo dojrzałe, trafnie rozwiązane metodologicznie, które ukazuje strajki szkolne w Prusach Zachodnich w sposób sumienny, wnikliwy i odkrywczy.

Autorka we „Wstępie” określiła zasięg terytorialny, przedmiotowy i chronologiczny pracy. Rejencje: gdańska i kwidzyńska stanowią obszar i granice badań. Bezwzględną większość ludności zamieszkującej wymienione tereny stanowili Niemcy. Jednocześnie polska mniejszość narodowa to w przeważającej mierze Kaszubi, posługujący się językiem - gwarą kaszubską. Nasuwa to od razu pytanie: w jakim stopniu i zakresie obrona języka ojczystego podczas omawianych strajków szkolnych była obroną literackiego języka polskiego i gwarowego. Kaszubi zawsze podkreślali swoją przynależność do Polski i narodu polskiego.

Zakres chronologiczny pracy nie jest ograniczony latami wymienionymi w jej tytule, co zresztą podkreśla autorka, formułując we „Wstępie” cel pracy; mieści się w okresie od upadku Księstwa Warszawskiego, które obejmowało część Prus Zachodnich oraz utworzenia w 1816 r. dwóch rejencji: gdańskiej (8 powiatów) i kwidzyńskiej (13 powiatów), a także dostosowania przez Watykan, we współpracy z rządem Prus, administracji kościelnej do ustanowionego przez pruskich zaborców podziału administracyjnego (1821 r.) do represji władz pruskich wobec uczestników strajków - dzieci, nauczycieli, księży i rodziców strajkujących dzieci po wygaśnięciu strajków w 1907 r.

Zakres przedmiotowy pracy obejmuje: genezę, przebieg oraz metody i formy przeciwdziałania strajkom szkolnym przez pruskie władze państwowe, działania polskich mieszkańców Prus Zachodnich w obronie języka ojczystego, tak przed strajkami, w czasie ich trwania, jak i po zakończeniu. Celom, zakresowi chronologicznemu, merytorycznemu i terytorialnemu podporządkowana jest struktura pracy, która jako całość ma układ chronologiczno-problemowy. Dotyczy to też struktury wszystkich czterech rozdziałów.

Zdaniem L. Burzyńskiej-Wentland literatura podstawowa na temat strajków szkolnych w Prusach Zachodnich w latach 1906-1907 - przywołana w pracy i ujęta w bibliografii pracy - wymaga weryfikacji. Publikacje na ten temat A. Bukowskiego ${ }^{3}$, K. Trzebiatowskiego ${ }^{4}, \mathrm{~K}$. Wajdy ${ }^{5}$, które stanowiły do tej pory główne źródło informacji o straj-

${ }^{3}$ A. Bukowski, Strajk szkolny na Pomorzy Gdańskim w latach 1906-1907, „Studia i Materiały do Dziejów Wielkopolski i Pomorza" t. III, 1957, z. 1.

${ }^{4}$ K. Trzebiatowski, Strajki szkolne na Pomorzu w początkach XX wieku. Materialy z dziejów szkolnictwa Ziemi Gdańskiej, Gdańsk 1968.

${ }^{5}$ K. Wajda, Strajk szkolny z lat 1906-1907 na wsi wielkopolskiej i pomorskiej, „Studia i Materiały do Dziejów Wielkopolski i Pomorza" t. III, 1957, z. 1. Przypisy 2-5 podano w brzmieniu nadanym przez L. Burzyńską-Wentland (s. 8-9). 
kach szkolnych, nadal zachowuja swa wartość naukowa, aczkolwiek część zawartych $w$ nich ustalen ma charakter hipotez wymagajacych uzupetnienia lub nawet reinterpretacji. Dotychczasowa historiografia na temat będący przedmiotem pracy nie wykracza poza badania wymienionych autorów. Nie ukazały się prace zwarte na ten temat. Problematyka strajków szkolnych nie doczekała się do tej pory monografii - uważa autorka pracy. Jednocześnie pisze, że książka Johna J. Kulczyckiego ${ }^{6}$ jest najnowszą, najpełniejszą i najbardziej wartościową publikacją monograficzną poświęconą strajkom szkolnym w zaborze pruskim.

Rozdział I „Geneza strajków szkolnych w Prusach Zachodnich w latach 1906-1907” jest podzielony na pięć podrozdziałów (ss. 14-63). W pierwszym z nich autorka prezentuje tło polityczne, gospodarcze i społeczne w Prusach Zachodnich w XIX w. Nie wspomina jednak faktu, że znaczna część tych ziem od 1807 do 1812 r. wchodziła w skład Księstwa Warszawskiego jako jego departamenty (np. Departament Bydgoski sięgający do Bałtyku), o czym obszernie pisze Marian Kallas?. Treść podrozdziału została szeroko udokumentowana pracami wykazanymi w przypisach. Dotyczy to zwłaszcza takich problemów, jak struktura administracyjna Prus Zachodnich, sytuacja wyznaniowa i językowa w końcu XIX w. (tab. 1, s. 17 ). Autorka ukazuje wpływ Wiosny Ludów na zahamowanie procesu germanizacji, podkreśla, że do lat czterdziestych XIX w. ludność polska szybko ulegała germanizacji. Wiosna Ludów wraz z hasłami prawa do wolności stanowiła przełom w procesie kształtowania się polskiej świadomości narodowej.

Analizując skutki wojny francusko-pruskiej, utworzenie II Rzeszy Niemieckiej i całokształt polityki żelaznego kanclerza Otto von Bismarcka przedstawia sytuację ludności polskiej zaboru pruskiego, w tym Prus Zachodnich. Po upadku władzy Bismarcka polityka władz Prus wobec Polaków nie zmieniła się generalnie do początków XX w. Tę część pierwszego rozdziału mogły dodatkowo wzmocnić prace niektórych autorów o uznanym, wysokim autorytecie naukowym i merytorycznej kompetencji. Należą do nich zwłaszcza: Henryk Mościcki i Jan Cynarski ${ }^{8}$, Eugeniusz Tarle ${ }^{9}$, Janusz Pajewski ${ }^{10}$, Antoni Czubiński ${ }^{11}$, Janusz Karwat ${ }^{12}$.

Bezpośrednio z brzmieniem tematu pracy koresponduje tytuł drugiego podrozdziału „Polityka szkolna w Prusach Zachodnich”. Ta właśnie germanizacyjna i antypolska polityka wzmagała i potęgowała opór ludności polskiej. Nasilenie tego oporu nastąpiło pod

${ }^{6}$ J.J. Kulczycki, Strajki szkolne w zaborze pruskim 1901-1907. Walka o dwujęzyczna oświatę, Poznań 1993.

${ }^{7}$ M. Kallas, Administracja Księstwa Warszawskiego, Wydawnictwo Uniwersytetu Mikołaja Kopernika, Toruń 1962.

${ }^{8}$ H. Mościcki, J. Cynarski, Historia XX wieku - 1900-1934, Nakładem Księgarni J. Przeworskiego, Warszawa 1936.

9 E. Tarle, Dzieje Europy 1871-1919, Wydawnictwo Książka i Wiedza, Warszawa 1961.

10 J. Pajewski J., Historia powszechna 1871-1918, Wyd. dziewiąte, Wydawnictwo Naukowe PWN, Warszawa 2001.

11 A. Czubiński, Europa w XX wieku, Wydawnictwo Poznańskie, Poznań 2002.

12 J. Karwat, Od idei do czynu. Myśl i organizacje niepodległościowe w Poznańskiem w latach 1887-1919, Wydawnictwo Poznańskie, Poznań 2002. 
wpływem rewolucji 1905 r. w zaborze rosyjskim oraz strajków szkolnych w Poznańskiem w 1906 r. W ostatniej części rozdziału I autorka ukazała wpływ prasy pomorskiej, zwłaszcza „Gazety Grudziądzkiej” i „Gazety Toruńskiej” na wybuch strajków szkolnych w rejencjach gdańskiej i kwidzyńskiej. Autorka przytacza tytuły nielicznych gazet niemieckich, które popierały strajki szkolne dzieci polskich. Były to: „Posener Neueste Nachrichten”, „Germania, Schlesische Zeitung” oraz „Frankfurter Zeitung”. Następnie wymienia aż 11 gazet niemieckich potępiających strajki szkolne dzieci polskich.

Przebiegowi strajków na opisywanym terenie (rejencja gdańska i kwidzyńska) poświęcony jest rozdział II, który rozpoczyna się opisem form działania rodziców i ich dzieci na początku strajków, podając konkretne przykłady, jak wręczanie przez dzieci nauczycielom pism od rodziców w sprawie udzielania nauk katechizmowych w języku polskim wraz z informacją o zakazie uczestnictwa dzieci w lekcjach religii prowadzonych w języku niemieckim, zachowania dzieci w czasie lekcji. Zwraca uwagę, że formy strajków wzorowane były na strajku dzieci we Wrześni w 1901 r.

Powołując się na K. Kubika autorka pisze, że pierwszy strajk w Prusach Zachodnich rozpoczął się 11 lipca 1906 r. w Rątach w powiecie kartuskim. Jednocześnie zwraca uwagę, że dane te nie zostały potwierdzone w trakcie przeprowadzonych badań, a w cytowanej publikacji nie wskazano źródła pochodzenia danych ${ }^{13}$.

Drugi strajk - według ustaleń L. Burzyńskiej-Wentland - odbył się 9 października 1906 r. w Pałubinie w powiecie kościerskim. Do masowych strajków doszło w październiku 1906 r. Do końca tego roku strajki swym zasięgiem objęły 391 szkół (rejencja kwidzyńska - 255, rejencja gdańska - 136). Szczegółowe dane we wszystkich powiatach obydwu rejencji autorka zamieściła w tabeli 2, a liczby uczestników strajków w tabeli 3 i 4. Kolejno zamieszczone tabele (5-15) zawierają szczegółowe dane o przebiegu i liczbie strajków szkolnych w poszczególnych powiatach Prus Zachodnich. Strajki szkolne zakończyły się w lipcu przed letnimi wakacjami. Po strajku szkolnym w m. Łebno w powiecie wejherowskim i m. Bukowiny w powiecie starogardzkim nie podejmowano już nowych prób wymuszenia na nauczycielach nauczania religii w języku polskim.

Ponury obraz wyłania się z treści całego rozdziału III, zatytułowanego: „Metody i formy przeciwdziałania strajkom szkolnym". Opisano w nim system represji i nacisków w stosunku do dzieci uczestniczących w strajkach i ich rodziców, redaktorów gazet, księży a także innych osób popierających strajki szkolne. W 13 podrozdziałach rozdziału trzeciego podjęto próbę określenia rozmiaru różnorodnych form represji, typów kar.

Oprócz tortur cielesnych i słownego lżenia stosowano karne godziny popołudniowe, zwane popularnie ,,aresztem”. Jak na ironię, za te godziny nauczyciele-germanizatorzy otrzymywali dodatkowe wynagrodzenie z budżetu samorządowego. W tym czasie przeważnie odbywały się lekcje dodatkowe z języka niemieckiego.

Przenoszenie dzieci polskich do niższych klas lub pozostawianie w szkole podstawowej po 14 roku życia tylko w części było uzasadnione miernymi wynikami w nauce -

13 Dotyczy publikacji K. Kubik, Szkolnictwo i oświata w zaborze pruskim, w: Dzieje szkolnictwa i oświaty na wsi polskiej do 1918 r., pod red. S. Michalskiego, Warszawa 1982. Przypis podano w oryginalnym brzmieniu zawartym w pracy. 
czasem z powodu upośledzenia umysłowego lub skrajnego ubóstwa rodziców. Najczęściej podyktowane było zemstą za uporczywe posługiwanie się językiem polskim i udział w strajkach szkolnych. Skrajnymi formami antypolskich represji były też wydalenia starszego rodzeństwa strajkujących dzieci z gimnazjów oraz usunięcia samych strajkujących ze szkół, a także zwalnianie ojców tych dzieci z pracy. Inne, równie lub jeszcze bardziej dotkliwe kary - represje, to: odbieranie rent inwalidzkich, kary pieniężne, zwalnianie z funkcji w dozorach szkolnych, kary więzienia dla rodziców lub opiekunów dzieci, umieszczanie dzieci w domach poprawczych.

Autorka podkreśla, że po stronie nauczycieli stawały pruskie sądy, które za jaskrawe nadużycia i naruszanie prawa uniewinniały ich lub skazywały na bardzo łagodne kary. Władze oświatowe wyróżniały tych nauczycieli.

Rozdział zamykają dane liczbowe o rozmiarach kar i represji.

Nie umniejszając wartości, i naukowej rzetelności pozostałych rozdziałów, warto podkreślić, że rozdział III jest w szczególności rzetelnie udokumentowanym rozdziałem.

Ostatni, IV rozdział pracy „Działania społeczeństwa polskiego w obronie języka ojczystego a strajki szkolne” jest największy pod względem objętości, a zarazem najbardziej zróżnicowany przedmiotowo. Ukazuje w szerszym kontekście walkę różnych środowisk, odłamów i organizacji polskich z germanizacją i asymilacją. Jak już wspomniano w poprzednich rozdziałach, inspiracją ogólną dla Prus Zachodnich były strajki szkolne w Poznańskiem. Strajk dzieci polskich we Wrześni w 1901 r. zaowocował w historii i kulturze polskiej Rotą Marii Konopnickiej i muzyką do niej Feliksa Nowowiejskiego. Pieśń, która długo była faktycznie hymnem polskim, do dziś jest często uważana za drugi hymn, obok Mazurka Dąbrowskiego. W obronie strajkujących dzieci polskich i ich rodziców w Prusach Zachodnich stanął laureat nagrody Nobla, Henryk Sienkiewicz. Autorka słusznie przytacza (Aneks nr 1, s. 208-210) pełny tekst listu otwartego Henryka Sienkiewicza do cesarza Niemiec Wilhelma II, zamieszczonego na łamach „Czasu” 19 listopada 1906 r. Treść listu odnosi się nie tylko do losu dzieci czy w ogóle Polaków w Prusach Zachodnich, ale też całego zaboru pruskiego. Pisał on bowiem: Wasza Cesarska Mość! Miara w prześladowaniu ciat i dusz jest przebrana! Bezduszne jest takie państwo, które nie baczac na to, że nawet zwierz musi mieć swoje legowisko, zabrania Polakowi wznieść sobie na własnym kawałku ziemi dach nad głowa [...]. Słowa manifestu królewskiego z roku 1867 zaręczaja polskim poddanym, że przez wcielenie ich do Pótnocnoniemieckiego Związu ani ich język, ani ich religia nie doznaja uszczerbku $i$ że wewnątrz Związu maja pozostać Polakami, zachować język i obyczaje. Jakże te królewskie słowa i obietnice zostały dotrzymane...? (s. 209).

Najczęstszymi i najbardziej rozpowszechnionymi formami działań ludności polskiej w obronie języka polskiego były: zebrania, wiece oraz pisanie zbiorowych petycji i publikowanie ich na łamach takich czasopism, jak: „Pielgrzym”, „Gazeta Grudziądzka”, „Gazeta Toruńska”, „Dziennik Poznański” i inne.

Ważną rolę w walce z germanizacją i obronie polskości odegrali polscy posłowie do sejmu pruskiego i Koła Polskiego w parlamencie Rzeszy Niemieckiej. Autorka przytacza treści ich wystąpień. 
Niejednolita była postawa duchowieństwa katolickiego wobec strajków szkolnych i działań rodziców w ich obronie. Duchowieństwo katolickie zostało ograniczone w zakresie swej społecznej, a nawet ściśle religijnej działalności, w okresie Kulturkampfu. Duchowni i ludność polska zostały szczególnie dotknięte ustawami: ustawa o nadzorze szkolnym z roku 1872 i ustawa usuwająca język polski z lekcji religii ze wszystkich szczebli nauczania oprócz najniższego w szkołach ludowych, a także ustawa z $1873 \mathrm{r}$. o kształceniu i zatrudnianiu duchowieństwa. Ograniczała ona kontakt księży katolickich z dziećmi tylko do nauczania w kościele w ramach przygotowań do Pierwszej Komunii Świętej. Naukę katechizmu prowadzili nauczyciele w szkole. W 1903 r. ukazał się Podręcznik do domowej nauki religii św. rzymsko-katolickiej. Na jego podstawie księża katoliccy w zaborze pruskim prowadzili w kościołach naukę przygotowawczą (w języku polskim) do Pierwszej Komunii Świętej. Autorka zamieszcza (na s. 166) fotokopię strony tytułowej tego podręcznika.

Wiosną 1906 r. w prowincji poznańskiej władze zniosły nauczanie religii w języku polskim w szkołach elementarnych. Zmian dokonano w 203 szkołach prowincji. Nie pomogła prośba arcybiskupa gnieźnieńskiego i poznańskiego Floriana Stablewskiego do nadprezydenta Wilhelma Waldowa o wstrzymanie akcji rugowania języka polskiego z lekcji religii i pozostawienie zwyczaju odmawiania po polsku modlitwy na początku lekcji. Nadprezydent odrzucił prośbę. Arcybiskupowi radził zaprzestania przez podległe mu duchowieństwo działań wprowadzających niepokój społeczny.

Biskup diecezji chełmińskiej (z siedzibą w Pelplinie) Augustyn Rosentreter, będąc Niemcem, zajął stanowisko ugodowe, twierdząc, że wznosi się ponad podziały narodowe. Większość duchowieństwa w parafiach popierała Polaków w ich walce o obronę języka ojczystego, czynnie wspierała różne formy protestów. Spotykała się z odwetem ekonomicznym (kary pieniężne) i sądowo-policyjnym (przykłady na s. 171-173). Autorka zamieszcza zbiorową fotografię skazanych i więzionych księży oraz fotokopię wyroku Sądu Najwyższego Rezerwy w Lipsku (Leipzig) z 28 czerwca 1907 r. zatwierdzającego wyroki na księży katolickich w Lubawie (s. 177). Przychylnie do polityki rządu pruskiego wobec Polaków ustosunkował się papież i większość dygnitarzy z kurii rzymskiej. Papież nigdy nie potępił prześladowania dzieci polskich za to, że domagały się nauczania religii w języku ojczystym.

Końcowym podrozdziałem rozdziału IV i całej pracy jest „Stosunek prasy pomorskiej do strajków”. Chodzi oczywiście o prasę polską w Prusach Zachodnich. Największymi i najważniejszymi tytułami prasowymi były: „Gazeta Gdańska”, „Gazeta Grudziądzka”, „Pielgrzym” i „Gazeta Toruńska”. Najbardziej aktywnie popierały strajki szkolne, wspierały duchowo rodziców i dzieci, wzywały do wytrwania w oporze - „Gazeta Grudziądzka”, której twórcą, właścicielem i ideologiem był Wiktor Kulerski i „Gazeta Toruńska”. W „Gazecie Toruńskiej” postulowano, by biskupi cofnęli prawo nauczania religii nauczycielom - germanizatorom. Jeżeli księża biskupi odejma nauczycielom misje kanoniczna, to rzad nie znajdzie sądu, który by śmiat karać rodziców za nieposyłanie dzieci na naukę religii udzielana bez uprawnień Kościoła, a „Gazeta Grudziądzka” zalecała też wprost rodzicom nie posyłać dzieci na lekcje religii udzielane po niemiecku, gdyż [...] większa zbrodnie popetnia ten, kto dobrowolnie pozwoli się zniemczyć (s. 190). 
Obydwie gazety oraz redagowany w Pelplinie, siedzibie niemieckiego biskupa chełmińskiego, „Pielgrzym” były przeciwne uczestnictwu uczniów szkół średnich w strajkach.

Redaktorzy, zwłaszcza „Gazety Grudziądzkiej” byli pociągani do odpowiedzialności sądowej. Za tematykę strajkową wytoczono „Gazecie” łącznie 67 procesów. Na kary więzienia za te same przestępstwa (popieranie) strajkowe skazano na kary więzienia redaktorów „Gazety Gdańskiej” i „Gazety Toruńskiej” (s. 192).

Jednym z głównych następstw strajków szkolnych w zaborze pruskim było zwycięstwo polskich kandydatów na posłów do Reichstagu 25 stycznia 1907 r. Liczba posłów Koła Polskiego w parlamencie niemieckim wzrosła z 16 do 20. Wzmogło ono walkę w obronie polskości pod pruskim zaborem. Strajki szkolne wytworzyly w społeczeństwie polskim Prus Zachodnich poczucie jedności. Wspólna walka z zaborca przyczyniła się do wzrostu polskiej świadomości narodowej oraz ożywiła działalność polskich organizacji (s. 195).

Autorka pracy osiągnęła cele określone we „Wstępie”. Ukazała społeczno-polityczne, ekonomiczne i kulturowe przyczyny strajków szkolnych w Prusach Zachodnich, ich przebieg i różne formy oraz metody zwalczania strajków przez władze pruskie. Dużo miejsca poświęciła działaniom polskim - rodziców, prasy, polskich parlamentarzystów w sejmie pruskim i Reichstagu Rzeszy, a także części duchowieństwa katolickiego w obronie mowy ojczystej i strajkujących na tym tle dzieci polskich. Wykorzystała przy tym bogate źródła drukowane, wycinkowo traktujące o temacie.

Sądzę, że praca została napisana zasadniczo na podstawie badań historyczno-pedagogicznych $^{14}$. W pracy ujawnił się należycie sposób opanowania przez autorkę pracy metody naukowej, stosowanie terminologii naukowej oraz zasad poprawnego pisarstwa naukowego. Nie budzi zastrzeżeń analiza tematu pracy w celu jego uzasadnienia jako problemu badawczego oraz wyszczególnienia problematyki pracy. Dotyczy to również rzeczowego układu pisarskiego pracy, krytyki literatury przedmiotu, stylu pisarstwa naukowego oraz wstępu i zakończenia. Pracę cechuje ścisłość i dokładność naukowa, wystarczające uzasadnienie twierdzeń naukowych, obiektywizm naukowy i jasność wywodów naukowych, a także zasada „oszczędności pisania”, właściwa budowa i staranny układ treści ${ }^{15}$.

Pracę z powodzeniem można rekomendować do wykorzystania w badaniach historyczno-pedagogicznych i edukacji historyczno-pedagogicznej.

Książka Lidii Burzyńskiej-Wentland jest wartościową publikacją. Niewątpliwie wpisuje się w problematykę badań regionalnych oraz dyskusję nad ich kształtem ${ }^{16}$. W ewentualnym nowym wydaniu książki zasadnym byłoby określenie osób, do których praca kierowana jest w szczególności (historycy wychowania, badacze dziejów regionu, stu-

${ }^{14}$ Zob. Konteksty $i$ metody $w$ badaniach historyczno-pedagogicznych, red. T. Jałmużna, I. Michalska, G. Michalski, Oficyna Wydawnicza „Impuls”, Kraków 2004.

15 Zob. rozważania na temat pisarstwa i piśmiennictwa naukowego zawarte w pracy J. Pieter, Z zagadnień pracy naukowej, Zakład Narodowy im. Ossolińskich, Wrocław 1974, ss. 104-125.

${ }^{16}$ Zob. O nowy model historycznych badań regionalnych, pod red. Krzysztofa A. Makowskiego, Instytut Zachodni, Centrum „Instytut Wielkopolski” Uniwersytetu im. Adama Mickiewicza w Poznaniu, Poznań 2007. 
denci, członkowie rodzin, których antenaci brali udział w strajkach), oraz wprowadzenie indeksu rzeczowego i indeksu osób.

W pracy zdarzają się błędy i niedopatrzenia. Na przykład w tabeli „Sytuacja wyznaniowa i językowa w Prusach Zachodnich w 1900 r.” (s. 17 ) podano za J. Buzkiem dane dotyczące katolików, którzy stanowili, zgodnie z tabelą, 5,1\% ludności (800 304 osoby na 1563523 ogółu ludności). Na stronie 102 pracy czytamy o próbach wymuszenia na nauczycielach nauczania lekcji religii w języku polskim. Prawdopodobnie autorka miała na myśli prowadzenie lekcji religii.

Anna Kołodziej

\section{Alicja Daniela Kicowska, Nauczyciele szkól rolniczych na Warmii i Mazurach (1945-1989), Wydawnictwo Uniwersytetu Warmiń- sko-Mazurskiego w Olsztynie, Olsztyn 2009, ss. 186}

Literatura dotycząca problematyki nauczycieli z zastosowaniem badań biograficznych cieszy się coraz większą popularnością i dorobkiem ${ }^{17}$. Mniej jest natomiast opracowań podejmujących tę tematykę w ujęciu regionalnym. W odniesieniu do terenu Warmii i Mazur, poza pracą T. Filipkowskiego ${ }^{18}$, występuje wyraźny deficyt opracowań koncentrujących się na biografiach nauczycieli. Książka A. D. Kicowskiej wypełnia tę lukę, a oryginalność pracy wiąże się również z wkładem recenzowanej publikacji w nurt badań najnowszej historii wychowania i pedeutologii historycznej. Autorka pracy, jak sama zaznaczyła we „Wstępie”, nie miała bowiem ambicji stworzenia słownika biograficznego nauczycieli szkół rolniczych na Warmii i Mazurach, lecz cel jej zamierzeń sprowadzał się do ukazania środowiska nauczycieli szkół rolniczych $w$ wymiarze zbiorowym (ilościowym) i indywidualnym z akcentem na biografię edukacyjno-zawodowa w kontekście przemian szkolnictwa rolniczego.

Recenzowana praca składa się z wykazu skrótów, wstępu, dwóch części, zakończenia i bibliografii. W konstrukcji pracy przyjęty został układ chronologiczno-problemowy.

Merytoryczne omówienie recenzowanej pracy należy rozpocząć od „Wstępu”, w którym Autorka wskazała na potrzebę opracowań biografii zbiorowej interesującej ją grupy zawodowej, informując Czytelnika, że niniejsza praca jest pierwsza próba opisu środowiska nauczycieli pracujacych $w$ szkołach rolniczych na Warmii i Mazurach $w$ okresie

17 Zob. m.in. H. Jadam, Nauczycieli portret zbiorowy, Rzeszów 1986; K. Polak, Indywidualne teorie nauczycieli: geneza, badanie, kształtowanie, Kraków 1999; W. Dróżka, Młode pokolenie nauczycieli. Studium autobiografii młodych nauczycieli polskich lat dziewięćdziesiątych, wyd. 2, Kielce 2004; eadem, Nauczycielska dojrzałość. Pamiętniki średniego pokolenia nauczycieli 2004, Kielce 2005; eadem, Generacja wielkiej zmiany. Studium autobiografii średniego pokolenia nauczycieli polskich 2004, Kielce 2008; E. Kurantowicz, M. Nowak-Dziemianowicz (red.), Narracja - krytyka - zmiana, Wrocław 2007.

18 T. Filipkowski, Nauczyciele polscy w Niemczech w latach 1919-1939. Portret zbiorowy, Olsztyn 1991. 